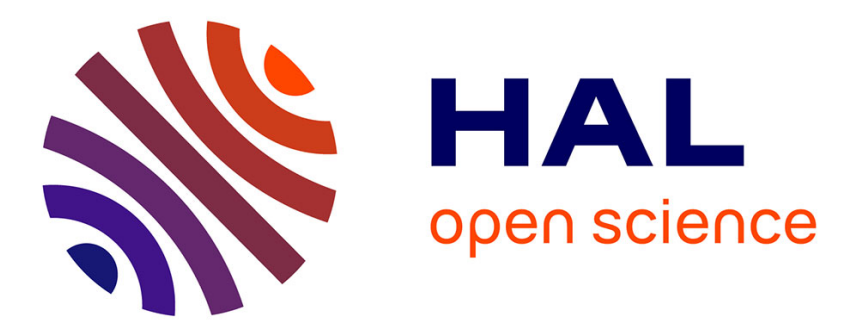

\title{
Plant oil-based epoxy resins from fatty diamines and epoxidized vegetable oil
}

Mylène Stemmelen, Vincent Lapinte, Jean-Pierre Habas, Jean-Jacques Robin

\section{To cite this version:}

Mylène Stemmelen, Vincent Lapinte, Jean-Pierre Habas, Jean-Jacques Robin. Plant oil-based epoxy resins from fatty diamines and epoxidized vegetable oil. European Polymer Journal, 2015, 68, pp.536545. 10.1016/j.eurpolymj.2015.03.062 . hal-01162088

\section{HAL Id: hal-01162088 \\ https://hal.science/hal-01162088}

Submitted on 10 Jun 2015

HAL is a multi-disciplinary open access archive for the deposit and dissemination of scientific research documents, whether they are published or not. The documents may come from teaching and research institutions in France or abroad, or from public or private research centers.
L'archive ouverte pluridisciplinaire HAL, est destinée au dépôt et à la diffusion de documents scientifiques de niveau recherche, publiés ou non, émanant des établissements d'enseignement et de recherche français ou étrangers, des laboratoires publics ou privés. 


\title{
Plant oil-based epoxy resins from fatty diamines and
}

\section{epoxidized vegetable oil}

\author{
Mylène Stemmelen', Vincent Lapinte*,1, Jean-Pierre Habas ${ }^{1}$, Jean-Jacques Robin ${ }^{1}$
}

${ }^{1}$ Institut Charles Gerhardt Montpellier UMR5253 CNRS-UM2-ENSCM-UM1 - Equipelngénierie et Architectures Macromoléculaires, Université Montpellier II cc1702, Place EugèneBataillon, 34095 Montpellier, France. E-mail: vincent.lapinte@univ-montp2.fr; Fax: +33-467144028; Tel: +33-467144832

*Correspondence: (Vincent Lapinte, Institut Charles Gerhardt Montpellier UMR5253 CNRS-UM2-ENSCM-UM1, EquipeIngénierieet Architectures Macromoléculaires, Université Montpellier II cc1702, Place EugèneBataillon. 34095 Montpellier Cedex 5, France. Tel: 334-67-14-48-32; Fax: 33-4-67-14-40-28; Vincent.Lapinte@univ-montp2.fr)

Running Title:Plant oil-based epoxy resins

Keywords:epoxy resin;fatty amine; thiol-ene coupling; vegetable oil. 


\begin{abstract}
Herein, the synthesis of vegetable oil-derived diamines by thiol-ene coupling (TEC) using cysteamine hydrochloride is reported. Despite the amine group in cysteamine that is unfavorable to TEC, fatty allylamide (FAl-A) provides an aminated fatty amide (AFA). Due to other diamides, the influence of the fatty structure on the TEC reactivity was demonstrated. The structures were characterized using FTIR and ${ }^{1} \mathrm{H}$ NMR spectroscopies, and the crosslinking of epoxidized linseed oil (ELO) with AFA was investigated using differential scanning calorimetry (DSC) and dynamic rheometry. The thermomechanical behavior of the plant oil-based thermoset was also characterized and compared toa commercial diamine based ona fatty dimer structure and a branched polyamine prepared from grapeseed oil. Finally, the beneficial effect of oxidation of the epoxy resin on thethermomechanical propertiesis highlighted.
\end{abstract}




\section{Introduction}

Based on the current petroleum issues (i.e., increase in the price and depletion of fossil reserves), biomass has attracted much attention as a feedstock for material applications. Various bio-based compounds (i.e., polysaccharides, rubbers or vegetable oils) could be used or modified to elaborate attractive polymers. ${ }^{1,}{ }^{2}$ The major advantages of vegetable oils include their relative abundance, low price and non-toxicity. Therefore, lipids have been widely exploited for the polymerization of bio-based thermoplastic materials, ${ }^{3-5}$ such as polyamide $11,{ }^{6}$ and thermoset materials, such as polyurethanes ${ }^{7-9}$ and epoxy resins ${ }^{10}$. Plant oil-based epoxy resins have attracted industrial interest due to the lack of bisphenolA or aromatic amine precursors that are carcinogenic or toxic. These resins are typically produced by catalytichomopolymerization of epoxydized oil ${ }^{1,11,12}$ or polyaddition using polyol, ${ }^{13,14}$ polyacid, anhydride in the presence of catalyst $^{15,16}$ or a polyamine hardener. ${ }^{17,18}$ Our study focuses on epoxy-amine thermosets with lipidic structures.

Few natural amines,aliphatic diamines (i.e., 1,4-butanediamine, 1,5-pentanediamine, 1,12dodecanediamine or 1,18-octadecanediamine) and triamine (spermidine), and bioderived amines, such as aminatedisosorbide, have been reported. ${ }^{19}$ Biermannet al. reviewed different methods for functionalizing unsaturated fatty acids with amine groups. ${ }^{20}$ The addition of sodium azide followed by the catalyzed reduction of the azide group into an amine was explored. Recently, Zhao et al. prepared secondary amines in a five steps process starting from epoxidized triglyceride. ${ }^{21}$ The oxirane groups were successively transformed into diols, bromines, and azide groups and finally reduced to amines. Some attempts at enzymatic biotransformationhave been 
successfully employed for the production of polyamines through the synthesis of an azadicarboxylate diethyl ester derivative of soybean oil. ${ }^{22,23}$ Under basic conditions, the derivative was converted to a substituted hydrazine. The same authors discovered another method for the production of an oleate-aniline using catalytic amounts of an ionic liquid. ${ }^{24}$ The use of a nitrile compound as an amine precursor after catalytic reduction has also been investigated with fatty acids. ${ }^{25}$ Finally, the addition of an excess amount of diamine to epoxidized vegetable oil can lead to an aminated fatty ester. ${ }^{26}$

Our group focused on the synthesis of fatty polyamines by thiol-ene coupling (TEC) to extend the bio-based amine series. In the literature, the TEC reaction is widely employed in polyol synthesis. However, only a few examples have described the synthesis of polyamine due to the formation of thiolate in the presence of an amine group, which affects the radical addition on the unsaturation. In a previous study, we reported the synthesis of an aminated oil bearing four amine groups per triglyceride using the thiol-ene reaction with cysteamine hydrochloride, and this oil was cured with commercial epoxidized linseed oil (ELO). ${ }^{27}$ Using the same synthetic strategy, Meier et al. modified fatty esters and used them for the preparation of polyamides and copolyamides. $^{28}$

In this study, we extend the thiol-ene coupling (TEC) methodology using cysteamine chloride with various fatty amides and diamides and demonstrate the influence of the fatty structure on the reaction efficiency. The curing process of the aminated fatty amide (AFA) and ELO was also studied at different temperatures, and the crosslinking kineticswere investigated using calorimetric and rheological analyses. Finally, the thermomechanical properties of the lipidic thermosets were characterized. 


\section{Materials and methods}

\section{Materials}

Absolute ethanol (EtOH, Carlo Erba), n-hexane (Carlo Erba), toluene (Sigma Aldrich), ethyl acetate (AcOEt, Carlo Erba), tetrahydrofuran (THF, Carlo Erba), isopropanol (iPrOH, Carlo Erba), dioxane, dichloromethane, hydrochloric acid ( $\mathrm{HCl}$, Carlo Erba), potassium hydroxide (KOH, Aldrich), sodium hydroxide ( $\mathrm{NaOH}$, Aldrich), $\mathrm{MgSO}_{4}$ (VWR), silica gel (Aldrich), hexylenediamine (HDA, Aldrich), ethylenediamine (EDA, Aldrich), p-xylenediamine (p-XDA, Aldrich), diethylenetriamine (DETA, Aldrich), allylamine (Aldrich), DCC (N,Ndicyclohexylcarbodiimide),DMAP (4(dimethylamino)pyridine), cysteamine hydrochloride (CAHC, Aldrich), 2,2-dimethoxy-2-phenylacetophenone (DMPA, 99\% Aldrich) and Priamine 1075 (Priamine, Croda) were used as received. Deuterated chloroform $\left(\mathrm{CDCl}_{3}\right)$ was purchased from SDS and used without purification. Epoxidized linseed oil (ELO) was generouslyprovided by ONIDOL, and the grapeseed oil was produced by SICA RAISINOR FRANCE. The grapeseed oil contained linoleic acid $(65.9 \% \mathrm{C} 18: 2)$, palmitoleic acid $(0.1 \% \mathrm{C} 16: 1)$, oleic acid $(22.7 \%$ $\mathrm{C} 18: 1)$, linolenic acid $(0.5 \% \mathrm{C} 18: 3)$ and palmitic and stearic acids (6.9\% C16:0) and (3.9\% C18:0). In addition, the grapeseed oil has 4.75 double bonds per triglyceride. The linseed oil containedlinolenic acid (47.4\% C18:3), unsaturated oleic (19.0\% C18:1), linoleic (24.1\% C18:2) and palmitic and stearic (6.0\% C16:0) and (2.5\% C18:0) and others (1.0).In addition, the linseed oil containssix carbon double bonds per triglyceride.

\section{Analytical Techniques}

${ }^{1} \mathrm{H}$ and ${ }^{13} \mathrm{C}$ NMR spectra were recorded using a Bruker AVANCE spectrometer $\left({ }^{1} \mathrm{H}\right.$ at $300 \mathrm{MHz}$, ${ }^{13} \mathrm{C}$ at $\left.75.47 \mathrm{MHz}\right) .{ }^{1} \mathrm{H}$ NMR spectra $(\delta, \mathrm{ppm})$ were recorded on a NMR BrukerAvance I 300 
$\mathrm{MHz}$ sonde QNP $\left({ }^{1} \mathrm{H} /{ }^{13} \mathrm{C} /{ }^{19} \mathrm{~F} /{ }^{\beta 1} \mathrm{P}\right)$ or on a BrukerAvance III $600 \mathrm{MHz}$ sonde QXI $\left({ }^{1} \mathrm{H} /{ }^{13} \mathrm{C} /{ }^{31} \mathrm{P} /{ }^{15} \mathrm{~N}\right)$ with $\mathrm{CDCl}_{3}$ as a solvent. The chemical shifts ${ }^{1} \mathrm{H}$ NMR spectra were referenced to the peak of residual $\mathrm{CHCl}_{3}$ at $7.26 \mathrm{ppm}$. The chemical shifts in the ${ }^{13} \mathrm{C}$ NMR spectra were referenced to $\mathrm{CDCl}_{3}$ at $77 \mathrm{ppm}$. Calorimetric analyses were carried out using a Star1 differential scanning calorimeter (DSC) from Mettler Toledo $^{\circledR}$ to determine the temperature zone characteristics of the crosslinking reaction. $10 \mathrm{mg}$ of the non-cured mixture was poured into an aluminum pan that was consecutively placed in the measurement-heating cell. An empty pan was used as a reference. These calorimetric experiments were achieved under inert atmosphere with a heating rate maintained at $5{ }^{\circ} \mathrm{C} \cdot \mathrm{min}^{-1}$. Fourier Transform infrared (FTIR) spectra were recorded with a Perkin-Elmer Spectrum 100 spectrometer equipped with an attenuated total reflectance (ATR) crystal ( $\mathrm{ZnSe})$. The thermo-oxidative stability of the reactive formulation was examined using a Q50 thermogravimetricanalyzer (TGA) from TA Instruments ${ }^{\circledR}$. The experiments consisted of registering the weight loss of the sample under an air flow $\left(25 \mathrm{~mL} \cdot \mathrm{min}^{-1}\right)$ as a function of temperature from ambient temperature to $550{ }^{\circ} \mathrm{C}$. Different experiments were performed with heating ratesof 1 to $10{ }^{\circ} \mathrm{C} \cdot \mathrm{min}^{-1}$. All of the rheological experiments were performed using a stress-controlled rheometer (AR2000Ex from TA Instruments ${ }^{\circledR}$ ) in dynamic mode. The viscoelastic experiments consisted of studying the kinetics of the crosslinking reaction using a cup-plate geometry as a sample container. The inner diameter of the cup was 40 $\mathrm{mm}$, and the inner diameter of the upper plate was much smaller $(5 \mathrm{~mm})$ to prevent parasitic side effects. The same rheometer was employed to investigate the evolution of the dynamic mechanical behavior of the cured sample as a function of the temperature. Because the cured samples were solid materials, the experiments were performed using a rectangular torsion geometry. Typical dimensions of the sample were $45 \mathrm{~mm} \times 10 \mathrm{~mm} \times 1 \mathrm{~mm}$. The 
thermomechanical tests were carried out at a heating rate of $3{ }^{\circ} \mathrm{C} \cdot \mathrm{min}^{-1}$ from -150 up to 200 ${ }^{\circ} \mathrm{C}$ and a fixed oscillating angular frequency, which ranged from 1 to $100 \mathrm{rad} . \mathrm{s}^{-1}$.

\section{Synthesis}

Synthesis of fatty acid (FA)

Grapeseed oil was dissolved in a solution of $\mathrm{KOH}$ (10 equiv) in ethanol $\left(1.7 \mathrm{~mol} \mathrm{~L}^{-1}\right)$, and the mixture was stirred for $3 \mathrm{~h}$ under reflux conditions. After cooling, the solution was neutralized with a $0.1 \mathrm{~N} \mathrm{HCl}$ solution. The fatty acid was dissolved in AcOEt and purified by washing the organic phase several times with brine. FA was isolated in $89 \%$ yield.

${ }^{1} \mathrm{H}$ NMR (300 MHz, $\mathrm{CDCl}_{3}, \delta$ ): 0.79-0.958 (m, 3H, $\left.\mathrm{CH}_{2}-\mathrm{CH}_{3}\right), 1.16-1.40\left(\mathrm{~m}, 17 \mathrm{H}, \mathrm{CH}_{2 \text { fatty chain }}\right.$ ), $1.60\left(2 \mathrm{H}, \mathrm{CH}_{2}-\mathrm{CH}_{2}-\mathrm{C}=\mathrm{O}\right), 1.88-2.1\left(\mathrm{~m}, 3.5 \mathrm{H},-\mathrm{CH}_{2}-\mathrm{CH}=\mathrm{CH}-\right), 2.35\left(\mathrm{t}, \mathrm{J}=7.5 \mathrm{~Hz}, 2 \mathrm{H},-\mathrm{CH}_{2}-\right.$ $\mathrm{C}=\mathrm{O}), 2.76\left(\mathrm{t}, \mathrm{J}=5.8 \mathrm{~Hz}, 1.2 \mathrm{H}, \mathrm{CH}=\mathrm{CH}-\mathrm{CH}_{2}-\mathrm{CH}=\mathrm{CH}\right), 5.21-5.42(\mathrm{~m}, 3 \mathrm{H}, \mathrm{CH}=\mathrm{CH}) ;{ }^{13} \mathrm{C} \mathrm{NMR}$ (75.47 MHz, $\mathrm{CDCl}_{3}, \delta$ ): $14.06\left(-\mathbf{C H}_{3}\right), 22.66-31.8\left(\right.$ other $\left.\mathbf{C H}_{2}\right), 33.9\left(\mathbf{C H}_{2}-\mathrm{C}=\mathrm{O}\right), 128-129.7$ $(\mathbf{C H}=\mathbf{C H}), 180.4(\mathbf{C}=\mathrm{O})$; IR: $v=3500-3000\left(\mathrm{O}-\mathrm{H}_{\text {acid }}\right), 3013(=\mathrm{C}-\mathrm{H}), 2918\left(\mathrm{C}-\mathrm{H}_{\mathrm{a}} v\right), 2853\left(\mathrm{C}-\mathrm{H}_{\mathrm{s}}\right.$ v), $1705\left(\mathrm{C}=\mathrm{O}_{\text {acid }} \mathrm{v}\right), 1459-1436\left(\mathrm{CH}_{2}\right.$ scissoring $), 1287\left(\mathrm{C}-\mathrm{O}_{\text {acid }} \delta\right), 926\left(\mathrm{OH}_{\delta}\right.$, plan deformation $)$, $720 \mathrm{~cm}^{-1}\left(\mathrm{CH}_{2 \delta}\right.$ rocking).

\section{Synthesis of fatty diamide (FDA)}

The diamine was heated at $150{ }^{\circ} \mathrm{C}$ (except for EDA, which was reacted at $110{ }^{\circ} \mathrm{C}$ for $20 \mathrm{~h}, \mathrm{bp}=$ $\left.118^{\circ} \mathrm{C}\right)$ and stirred in a flask equipped with a condenser under dry nitrogen. The fatty acid (2 equiv) was added dropwise (17 $\mathrm{ml}$ in $2 \mathrm{~h}$ ), and the mixture was left to stand for 5 hours. After cooling, the obtained fatty diamide was crystallized in a solvent mixture (acetone/toluene: 1/1). 
Fatty ethylene-diamide (EDA-FDA)

EDA-FDA was isolated in $40 \%$ yield.

mp $106{ }^{\circ} \mathrm{C} ;{ }^{1} \mathrm{H}$ NMR $\left(300 \mathrm{MHz}, \mathrm{CDCl}_{3}, \delta\right): 0.79-0.88\left(6 \mathrm{H}, \mathrm{CH}_{3}\right), 1.16-1.30\left(\mathrm{CH}_{2 \text { fatty chain }}\right), 1.55-$ $1.70\left(4.4 \mathrm{H}, \mathrm{CH}_{2}-\mathrm{CH}_{2}-\mathrm{C}=\mathrm{O}\right.$ and $\left.\mathrm{NH}\right), 1.9-2.05\left(7 \mathrm{H},-\mathrm{CH}_{2}-\mathrm{CH}=\mathrm{CH}-\right), 2.0-2.2\left(\mathrm{t}, 4 \mathrm{H}, \mathrm{CH}_{2}-\mathrm{C}=\mathrm{O}\right)$, $2.76\left(\mathrm{t}, 2.5 \mathrm{H}, \mathrm{CH}=\mathrm{CH}-\mathrm{CH}_{2}-\mathrm{CH}=\mathrm{CH}\right), 3.4\left(\mathrm{~s}, 3.9 \mathrm{H}, \mathrm{CH}_{2}-\mathrm{NH}\right), 5.21-5.42(\mathrm{~m}, 5.9 \mathrm{H}, \mathrm{CH}=\mathrm{CH}), 5.5$ $(1.8 \mathrm{H}, \mathrm{NH}) ;{ }^{13} \mathrm{C}$ NMR $\left(75.47 \mathrm{MHz}, \mathrm{CDCl}_{3}\right), \delta=14.03\left(\mathrm{CH}_{2}-\mathrm{CH}_{3}\right), 22.7-31.8\left(\mathrm{CH}_{2}\right), 36.7\left(\mathrm{CH}_{2^{-}}\right.$ $\mathrm{C}=\mathrm{O}), 40.2\left(\mathrm{CH}_{2}-\mathrm{NH}\right), 127.8-130.8(\mathbf{C H}=\mathbf{C H}), 174.4(\mathbf{C}=\mathrm{O}) ; \mathrm{IR}: v=3309(\mathrm{NH}), 3080(=\mathrm{C}-\mathrm{H})$, 2914 and $2846(\mathrm{C}-\mathrm{H}), 1636(\mathrm{C}=\mathrm{O}$ amide $), 1539(\mathrm{NH}), 1469\left(\mathrm{CH}_{2}\right.$ scissoring), 1417 (C-N stretching), $708\left(\mathrm{CH}_{2}\right.$ rocking $), 683 \mathrm{~cm}^{-1}\left(\mathrm{NH}_{\text {amide }} \gamma\right)$.

Fatty hexylene-diamide (HDA-FDA)

HDA-FDA was isolated in $91 \%$ yield.

mp $95^{\circ} \mathrm{C} ;{ }^{1} \mathrm{H}$ NMR $\left(300 \mathrm{MHz}, \mathrm{CDCl}_{3}, \delta\right): 0.79-0.88\left(6 \mathrm{H}, \mathrm{CH}_{3}\right), 1.16-1.30\left(\mathrm{CH}_{2 \text { fatty chain }}\right), 1.45-$ $1.55\left(\mathrm{CH}_{2}-\mathrm{CH}_{2}-\mathrm{NH}\right), 1.55-1.7\left(\mathrm{CH}_{2}-\mathrm{CH}_{2}-\mathrm{C}=\mathrm{O}\right), 1.9-2.05\left(7 \mathrm{H},-\mathrm{CH}_{2}-\mathrm{CH}=\mathrm{CH}-\right), 2 .-2.2(\mathrm{t}, 4 \mathrm{H}$, $\left.\mathrm{CH}_{2}-\mathrm{C}=\mathrm{O}\right), 2.74-2.78\left(\mathrm{t}, 2.7 \mathrm{H}, \mathrm{CH}=\mathrm{CH}-\mathrm{CH}_{2}-\mathrm{CH}=\mathrm{CH}\right), 3.2-3.3(\mathrm{dd}, \mathrm{J}=12.6 \mathrm{~Hz}, 6.3 \mathrm{~Hz}, 4 \mathrm{H}$, $\left.\mathrm{CH}_{2}-\mathrm{NH}\right), 5.21-5.42(\mathrm{~m}, 6.5 \mathrm{H}, \mathrm{CH}=\mathrm{CH}), 5.4-5.6(1.8 \mathrm{H}, \mathrm{NH}) ;{ }^{13} \mathrm{C} \mathrm{NMR}\left(75.47 \mathrm{MHz}, \mathrm{CDCl}_{3}, \delta\right)$ : $14.06\left(\mathbf{C H}_{3}\right), 22.7-31.8\left(\mathbf{C H}_{2}\right.$ fatty chain $), 36.9\left(\mathbf{C H}_{2}-\mathrm{C}=\mathrm{O}\right), 38.9\left(\mathbf{C H}_{2}-\mathrm{NH}\right), 128-129.7(\mathbf{C H}=\mathbf{C H})$, $173.2(\mathbf{C}=\mathrm{O})$; IR: $v=3300(\mathrm{NH}), 3005(=\mathrm{C}-\mathrm{H}), 2925$ and $2851(\mathrm{C}-\mathrm{H}), 1630\left(\mathrm{C}=\mathrm{O}_{\text {amide }}\right), 1530$ (NH bending), $1470\left(\mathrm{CH}_{2}\right.$ scissoring), 1411 (C-N stretching), $717\left(\mathrm{CH}_{2}\right.$ rocking), $681 \mathrm{~cm}^{-}$ ${ }^{1}\left(\mathrm{NH}_{\text {amide }} \gamma\right)$. 
Fatty DETA-diamide (DETA-FDA)

DETA-FDA was isolated in $57 \%$ yield.

mp 67 ${ }^{\circ} \mathrm{C} ;{ }^{1} \mathrm{H}$ NMR $\left(300 \mathrm{MHz}, \mathrm{CDCl}_{3}, \delta\right): 0.79-0.88\left(6 \mathrm{H}, \mathrm{CH}_{3}\right), 1.16-1.40\left(\mathrm{CH}_{2 \text { fatty chain }}\right), 1.55-$ $1.7\left(7 \mathrm{H}, \mathrm{CH}_{2}-\mathrm{CH}_{2}-\mathrm{C}=\mathrm{O}\right.$ and $\left.\mathrm{NH}-\mathrm{CH}_{2}\right), 1.9-2.05\left(7.5 \mathrm{H},-\mathrm{CH}_{2}-\mathrm{CH}=\mathrm{CH}-\right), 2-2.2(\mathrm{t}, \mathrm{J}=5.8 \mathrm{~Hz}, 4 \mathrm{H}$, $\mathrm{CH}_{2}-\mathrm{C}=\mathrm{O}$ ), 2.74-2.78 (t, 2.7H, $\mathrm{CH}=\mathrm{CH}-\mathrm{CH}_{2}-\mathrm{CH}=\mathrm{CH}$ and $\left.\mathrm{NH}-\mathrm{CH}_{2}\right), 3.30-3.40(\mathrm{dd}, \mathrm{J}=11.4 \mathrm{~Hz}$, $\left.5.7 \mathrm{~Hz}, 4 \mathrm{H}, \mathrm{CH}_{2}-\mathrm{NH}\right), 5.21-5.50(\mathrm{~m}, 6.5 \mathrm{H}, \mathrm{CH}=\mathrm{CH}), 5.9-6(1.6 \mathrm{H}, \mathrm{NH}) ;{ }^{13} \mathrm{C} \mathrm{NMR}(75.47 \mathrm{MHz}$, $\left.\mathrm{CDCl}_{3}, \delta\right): 14.03\left(-\mathrm{CH}_{3}\right), 22.7-31.80\left(\mathbf{C H}_{2 \text { fatty chain }}\right), 36.9\left(\mathbf{C H}_{2}-\mathrm{C}=\mathrm{O}\right), 39.15\left(\mathbf{C H}_{2}-\mathrm{NH}-\mathrm{C}=\mathrm{O}\right)$, $48.50\left(\mathrm{NH}-\mathrm{CH}_{2}\right), 128-130(\mathrm{CH}=\mathrm{CH}), 173.4(\mathrm{C}=\mathrm{O}) ; \mathrm{IR}: v=3309(\mathrm{NH}), 3008(=\mathrm{C}-\mathrm{H}), 2914$ and $2846(\mathrm{C}-\mathrm{H}), 1636\left(\mathrm{C}=\mathrm{O}_{\text {amide }}\right), 1539\left(\mathrm{NH}_{\text {amide }}\right.$ bending $), 1465\left(\mathrm{CH}_{2}\right.$ scissoring $), 1421\left(\mathrm{C}-\mathrm{N}_{\text {amide }}\right.$ stretching $), 1126$ (C-Namine), 723 ( $\mathrm{CH}_{2}$ rocking $), 681 \mathrm{~cm}^{-1}\left(\mathrm{NH}_{\text {amide }} \gamma\right)$.

Fatty p-xylylene-diamide ( $p$-XDA-FDA)

$p$-XDA-FDA was isolated in $66 \%$ yield.

mp $136{ }^{\circ} \mathrm{C} ;{ }^{1} \mathrm{H}$ NMR $\left(300 \mathrm{MHz}, \mathrm{CDCl}_{3}, \delta\right): 0.79-0.88\left(6 \mathrm{H}, \mathrm{CH}_{3}\right), 1.16-1.30\left(\mathrm{CH}_{2 \text { fatty chain }}\right), 1.55-$ $1.7\left(4.4 \mathrm{H}, \mathrm{CH}_{2}-\mathrm{CH}_{2}-\mathrm{C}=\mathrm{O}\right), 1.9-2.1\left(7.3 \mathrm{H}, \mathrm{CH}_{2}-\mathrm{CH}=\mathrm{CH}\right), 2 .-2.2\left(\mathrm{t}, 4 \mathrm{H}, \mathrm{CH}_{2}-\mathrm{C}=\mathrm{O}\right), 2.74-2.78(\mathrm{t}$, 2.6H, $\left.\mathrm{CH}=\mathrm{CH}-\mathrm{CH}_{2}-\mathrm{CH}=\mathrm{CH}\right), 3.4\left(\mathrm{~d}, 4 \mathrm{H}, \mathrm{CH}_{2}-\mathrm{NH}\right), 5.21-5.42(\mathrm{~m}, 6.2 \mathrm{H}, \mathrm{CH}=\mathrm{CH}), 5.7-5.8$ $(1.9 \mathrm{H}, \mathrm{NH}), 7.2\left(\mathrm{~s}, 3.9 \mathrm{H}, \mathrm{CH}=\mathrm{CH}_{\text {aromatic }}\right) ;{ }^{13} \mathrm{C} \mathrm{NMR}\left(75.47 \mathrm{MHz}, \mathrm{CDCl}_{3}, \delta\right): 14.1\left(\mathrm{CH}_{2}-\mathrm{CH}_{3}\right)$, 22.7-31.6 $\left(\mathbf{C H}_{2}\right), \quad 36.8 \quad\left(\mathbf{C H}_{2}-\mathrm{C}=\mathrm{O}\right), \quad 43.2 \quad\left(\mathbf{C H}_{2}-\mathrm{NH}\right), \quad 127.9 \quad\left(\mathbf{C H}=\mathbf{C H}_{\text {aromatic }}\right), \quad 128-130.2$ $(\mathbf{C H}=\mathbf{C H}), 137.8\left(\mathbf{C}-\mathrm{CH}_{2}-\mathrm{NH}\right), 172.9(\mathbf{C}=\mathrm{O})$; IR: $v=3290\left(\mathrm{NH}_{\text {amide }}\right), 3065(=\mathrm{C}-\mathrm{H}), 3008(=\mathrm{C}-\mathrm{H}$, stretching), 2923 and $2851(\mathrm{C}-\mathrm{H}), 1634\left(\mathrm{C}=\mathrm{O}_{\text {amide }}\right), 1545\left(\mathrm{NH}_{\text {amide }}\right.$ bending $), 1463\left(\mathrm{CH}_{2}\right.$ scissoring), $1420 \mathrm{~cm}^{-1}$ (C-N stretching).

$\left({ }^{1} \mathrm{H}\right.$ NMR spectra shown in supporting information) 


\section{Synthesis of fatty allyl-amide (FAl-A)}

The fatty allyl-amide was synthesized using a coupling reaction. A solution of fatty acid in anhydrous dichloromethane was mixed with DCC (0.1 equiv) using vigorous stirring for 15 minutes to activate the acid function. DMAP ( 0.5 equiv) was added as a catalyst. Then, the mixture was cooled to $0{ }^{\circ} \mathrm{C}$ with an icebath, and allylamine (2 equiv) was introduced dropwise. After $7 \mathrm{~h}$, the reaction was complete. Dicyclohexylurea (DCU), which was produced during the reaction, was removed by filtration because it was a solid salt. The non-reacted DCC and DMAP were removed by successive washing of the organic phase with an acidic aqueous solution, a $\mathrm{Na}_{2} \mathrm{CO}_{3}$ solution and a brine solution. The solution was concentrated under reduced pressure to yield a crude liquid that exhibited two spots on TLC (i.e., $N$-acetyl urea and fatty allyl-amide, which represented $90 \%$ of the mixture (calculated by ${ }^{1} \mathrm{H}$ NMR, spectra shown in supporting information)). Purification by chromatography on silica gel using mixtures of $n$-hexane-AcOEt $(90 / 10 \mathrm{v} / \mathrm{v})$ as eluents yielded two separated products as follows: $N$-acetyl urea and the desired fatty allyl-amide. FAl-A was isolated in $61 \%$ yield.

mp $7{ }^{\circ} \mathrm{C} ;{ }^{1} \mathrm{H}$ NMR $\left(300 \mathrm{MHz}, \mathrm{CDCl}_{3}, \delta\right): 0.79-0.88\left(3.3 \mathrm{H},-\mathrm{CH}_{3}\right), 1.16-1.30\left(19.6 \mathrm{H}, \mathrm{CH}_{2}\right.$ fatty chain), $1.63\left(2.15 \mathrm{H}, \mathrm{CH}_{2}-\mathrm{CH}_{2}-\mathrm{C}=\mathrm{O}\right), 1.92-2.07\left(3.7 \mathrm{H},-\mathrm{CH}_{2}-\mathrm{CH}=\mathrm{CH}-\right), 2.24-2.37\left(\mathrm{t}, 2 \mathrm{H}, \mathrm{CH}_{2^{-}}\right.$ $\mathrm{C}=\mathrm{O}), 2.74-2.78\left(\mathrm{t}, \mathrm{J}=5.8 \mathrm{~Hz}, \mathrm{CH}=\mathrm{CH}-\mathrm{CH}_{2}-\mathrm{CH}=\mathrm{CH}\right), 3.86-3.9\left(\mathrm{t}, \mathrm{J}=5.7 \mathrm{~Hz}, \mathrm{~J}=1.4 \mathrm{~Hz}, \mathrm{CH}_{2^{-}}\right.$ NH-C=O), 5.1-5.2 (2H, CH=CH$), 5.21-5.42(\mathrm{~m}, 3 \mathrm{H}, \mathrm{CH}=\mathrm{CH}), 5.44-5.7(0.85 \mathrm{H}, \mathrm{NH}), 5.77-5.9$ $\left(1 \mathrm{H}, \mathrm{CH}=\mathrm{CH}_{2}\right) ;{ }^{13} \mathrm{C}$ NMR $\left(75.47 \mathrm{MHz}, \mathrm{CDCl}_{3}, \delta\right): 14.3\left(-\mathrm{CH}_{3}\right), 22.5-31.9\left(\mathbf{C H}_{2}\right), 36.8\left(\mathrm{CH}_{2}-\right.$ $\mathrm{C}=\mathrm{O}), 41.8\left(\mathrm{CH}_{2}-\mathrm{NH}\right), 116.3\left(\mathrm{CH}=\mathrm{CH}_{2}\right), 128.0-129.7(\mathbf{C H}=\mathbf{C H}), 134.4\left(\mathrm{CH}_{2}=\mathbf{C H}\right), 172.8$ $(\mathbf{C}=\mathrm{O}) ; \mathrm{IR}: v=3281\left(\mathrm{NH}_{\text {amide }}\right), 3003(=\mathrm{C}-\mathrm{H}), 2923$ and $2852(\mathrm{C}-\mathrm{H}), 1645\left(\mathrm{C}=\mathrm{O}_{\text {amide }}\right), 1546$ ( $\mathrm{NH}_{\text {amide }}$ bending), $1460\left(\mathrm{CH}_{2}\right.$ scissoring $), 1417 \mathrm{~cm}^{-1}\left(\mathrm{C}-\mathrm{N}_{\text {amide }}\right)$. 
Synthesis of aminated fatty diamines (AFDA) and aminated fatty allylamide (AFA): Thiol-Ene Coupling (TEC)

The thiol-ene reaction was performed under UV irradiation using an annular cylindrical photoreactor where the UV lamp was inserted in a water cooled (approximately $20{ }^{\circ} \mathrm{C}$ ) double jacket tube immersed in a larger tube containing the raw materials. The stirred reactive mixture was irradiated from the center. The UV lamp was a HPK $125 \mathrm{~W}$ high-pressure mercury vapor lamp from HeraeusNoblelight (maximum energy at a wavelength of $365 \mathrm{~nm}$ with substantial radiations at 435, 313, 253 and $404 \mathrm{~nm}$ ). The entire reactor was placed within a darkened hood to isolate the vessel from stray light.

First, a fatty (di)-amide (fatty allyl amide with 2.5 double bonds per molecule and fatty diamidewith three double bonds per molecule determined by ${ }^{1} \mathrm{H}$ NMR), CAHC (3 equiv per double bond), and DMPA (0.1 equivper double bond) were dissolved in a minimal amount of solvent or a mixture of solvents at $40{ }^{\circ} \mathrm{C}$ to dissolve all of the components. The reactions were performed in a photoreactor where a UV lamp was inserted in a water-cooled (approximately 20 $\left.{ }^{\circ} \mathrm{C}\right)$ Pyrex jacket, which was immersed in a larger tube containing the raw materials. Irradiation was carried out for $24 \mathrm{~h}$. After the reaction, the solvent was evaporated, and a $\mathrm{Na}_{2} \mathrm{CO}_{3}$ saturated solution (e.g., $100 \mathrm{~mL}$ for $5 \mathrm{~g}$ of fatty allyl-amide) was added to dissolve the oil in the aqueous solution. The aqueous phase was washed twice with chloroform to eliminatethe photoinitiator. A $\mathrm{NaOH}$ solution was added to achieve a basic $\mathrm{pH}$. The organic phase containing the lipidic compound was washed at least five times with brine. OnceCAHC was eliminated, the organic phase was dried over $\mathrm{MgSO}_{4}$, and the solvent was removed by vacuum evaporation. 
Aminated fatty hexyldiamide (AFHDA) from HDA-FDA

AFHDA was isolated in $62 \%$ yield.

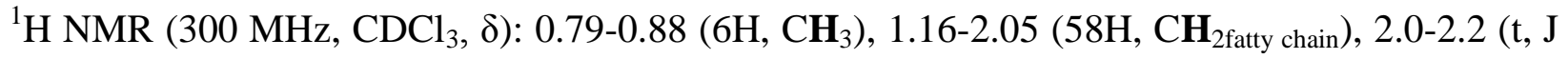
$\left.=7.5 \mathrm{~Hz}, 4 \mathrm{H}, \mathrm{CH}_{2}-\mathrm{C}=\mathrm{O}\right), 2.5-2.75\left(\mathrm{~m}, 4.4 \mathrm{H},-\mathrm{CH}_{2}-\mathrm{S}\right.$ and $\left.-\mathrm{CH}-\mathrm{S}\right), 2.8-3.0\left(\mathrm{~m}, 3.3 \mathrm{H}, \mathrm{CH}_{2}-\mathrm{NH}_{2}\right)$, 3.2-3.3 (dd, J = 12.6 Hz, J = 6.3 Hz, 4H, CH $2-\mathrm{NH}), 5.21-5.42(\mathrm{~m}, 2 \mathrm{H}, \mathrm{CH}=\mathrm{CH}), 5.4-5.6(\mathrm{NH})$.

Aminated fatty amide (AFA) from FAl-A

AFA was isolated in $93 \%$ yield.

${ }^{1} \mathrm{H}$ NMR $\left(600 \mathrm{MHz}, \mathrm{CDCl}_{3}, \delta\right): 0.79-0.88\left(\mathrm{~m}, 3.1 \mathrm{H},-\mathrm{CH}_{3}\right), 1.16-1.61\left(\mathrm{~m}, 30 \mathrm{H}, \mathrm{CH}_{2 \text { fatty chain }}\right.$ and $\mathrm{NH}_{2}$ ), 1.7-1.8 (q, 2.19H, $\left.\mathrm{CH}_{2}-\mathrm{CH}_{2}-\mathrm{NH}\right), 2.04-2.15$ (t, 2.1H, J = 7.7 Hz, 2.14H, CH $2-\mathrm{C}=\mathrm{O}$ ), 2.47$2.63\left(\mathrm{~m}, 7 \mathrm{H}, \mathrm{S}-\mathrm{CH}_{2}\right.$ and $\left.\mathrm{S}-\mathrm{CH}\right), 2.77-2.87\left(\mathrm{~m}, 4.2 \mathrm{H}, \mathrm{CH}_{2}-\mathrm{NH}_{2}\right), 3.26-3.35(\mathrm{dd}, 4.2 \mathrm{H}, \mathrm{J}=12.9$, 6.5 Hz, CH $\left.\mathbf{H}_{2}-\mathrm{NH}-\mathrm{C}=\mathrm{O}\right), 5.8-6(0.85 \mathrm{H}, \mathrm{NH}) ;{ }^{13} \mathrm{C} \mathrm{NMR}\left(75.47 \mathrm{MHz}, \mathrm{CDCl}_{3}, \delta\right): 14.3\left(-\mathrm{CH}_{3}\right)$, 22.49-31.9 $\left(\mathbf{C H}_{2}\right), 34.4$ and $36.0\left(\mathrm{CH}_{2}-\mathrm{CH}_{2}-\mathrm{NH}_{2}\right), 35.0\left(\mathrm{~S}-\mathrm{CH}-\mathrm{CH}_{2}\right), 36.8\left(\mathbf{C H}_{2}-\mathrm{C}=\mathrm{O}\right), 38.5$ $\left(\mathrm{CH}_{2}-\mathrm{NH}-\mathrm{C}=\mathrm{O}\right), 41.4\left(\mathrm{CH}_{2}-\mathrm{NH}_{2}\right), 45.8(\mathrm{CH}-\mathrm{S}),(\mathrm{C}=\mathrm{O})$ not visible.

IR: $v=3280\left(\mathrm{NH}\right.$ and $\left.\mathrm{NH}_{2 \mathrm{amine}}\right), 3069\left(\mathrm{NH}_{\text {amide }}\right), 2923$ and $2850(\mathrm{C}-\mathrm{H}), 1642\left(\mathrm{C}=\mathrm{O}_{\text {amide }}\right), 1547$ $\left(\mathrm{NH}_{\text {amide }}\right), 1453\left(\mathrm{CH}_{2}\right.$ scissoring $), 1417$ (C-N amide), $1070 \mathrm{~cm}^{-1}(\mathrm{C}-\mathrm{S}) .\left({ }^{1} \mathrm{H}\right.$ NMR spectra shown in supporting information). 


\section{Results}

Aminated fatty hardeners for epoxy resins were preparedin two stages, as shown in Figure 1.

First, the fatty acid (FA) was converted to a fatty diamide (FDA) or fatty amide (FAl-A) using a dimerization and coupling method, respectively. Second, the unsaturations were modified leading to aminated fatty diamide (AFDA) or aminated fatty amide (AFA) by a photo-induced thiol-ene reaction (photo-TEC) using cysteamine hydrochloride (CAHC).
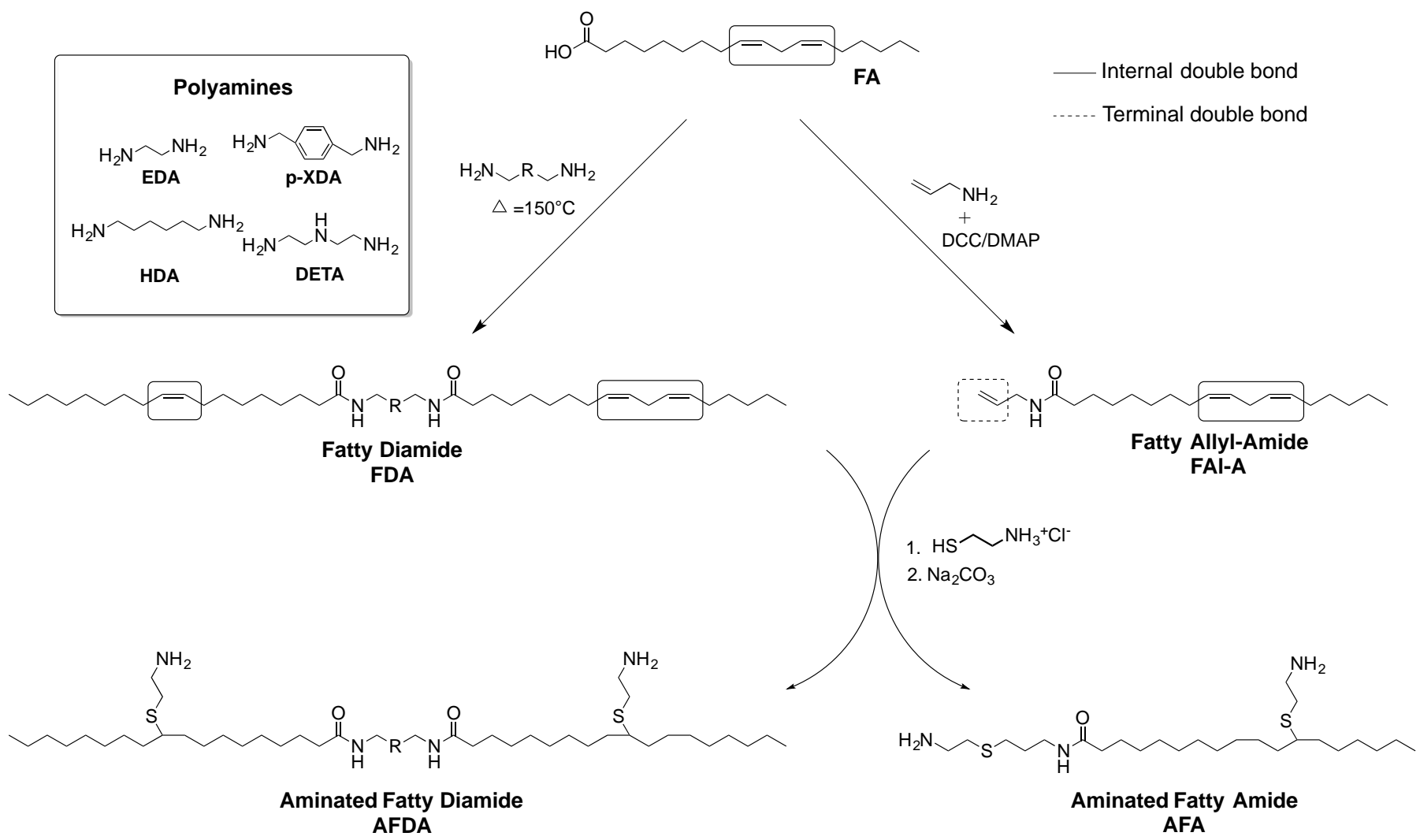

FIGURE 1Synthesis of aminated fatty (di)amides.

\section{Synthesis of fatty amides}

The fatty amides typically result from the reaction of fatty acids or triglycerides with ammonia $^{29}$ or an amine with an activated fatty acid, such as fatty acyl chloride. ${ }^{30}$ Lipases also 
produce fatty amides, such as oleoyl-N-methyl-glucamide, ${ }^{31}$ and catalyze ${ }^{32}$ the coupling between amines and fatty acids. Finally, the direct synthesis of fatty amides by heating triglycerides or their derivatives with amines has been widely reported and used in industry. ${ }^{33-36}$ As shown in Figure 1, the route based on the conversion of a fatty acid derived from grapeseed oil to fatty diamide (FDA) or mono amide (FAl-A) was selected. The synthesis of FDA was investigated by dimerization of a fatty acid with various diamines, such as ethylene diamine (EDA), hexylenediamine (HDA), p-xylylenediamine (p-XDA) and a triamine: diethylenetriamine (DETA). According to previous studies on the amidification of $\mathrm{FA},{ }^{37,38}$ the syntheses were conducted at high temperatures in bulk to yield 40 to $91 \%$ yield, which is in good agreement with previously reported results. ${ }^{38}$ However, a monoamide: fatty allyl-amide (FAl-A) was obtained in $61 \%$ yield by reacting the fatty acid and allylamine according to Steglich conditions. $^{32,39}$

The conversion of the fatty acid group into a fatty amide group was monitored by FTIR spectroscopy using the shift of the $\mathrm{C}=\mathrm{O}$ band from 1706 to $1629 \mathrm{~cm}^{-1}$ and the appearance of the amide group at $3306 \mathrm{~cm}^{-1}$ (stretching of $\mathrm{NH}$ ) and $1530 \mathrm{~cm}^{-1}$ (NH bending of amide). The conversion was also monitored by ${ }^{1} \mathrm{H}$ NMR spectroscopy in $\mathrm{CDCl}_{3}$. For all of the fatty (di)amides, the peaks corresponding to the internal and terminal unsaturations of the fatty chains were observed between 5 and $6 \mathrm{ppm}$ (internal ones at 5.2-5.5 ppm and terminal ones at 5-5.2 ppm/5.7-6.0 ppm), as shown in Figure 2 for allylamine. The disappearance of the characteristic peak corresponding to $\underline{\mathrm{C}}_{2}-\mathrm{C}=\mathrm{O}_{\text {acid }}(\mathrm{H}-2)$ at $2.3 \mathrm{ppm}$ as well as the appearance of a triplet at 2.1 ppm corresponding to $\underline{\mathrm{C}}_{2}-\mathrm{C}=\mathrm{O}_{\text {amide }}(\mathrm{H}-2)$ were also observed. In addition, a peak corresponding to $\underline{\mathrm{C}}_{2}-\mathrm{NH}-\mathrm{C}=\mathrm{O}$ appeared between 3 and $4 \mathrm{ppm}$ for some diamine structures. For FAl-A, this peak was located at $3.8 \mathrm{ppm}$. Therefore, the fatty mono- and diamides result from coupling 
between a fatty acid and mono-, di- and triamines. Fatty diamides (FDA) have 3 internal double bonds, and monoamide (FAl-A) has 2.5 double bonds including one in the terminal position.

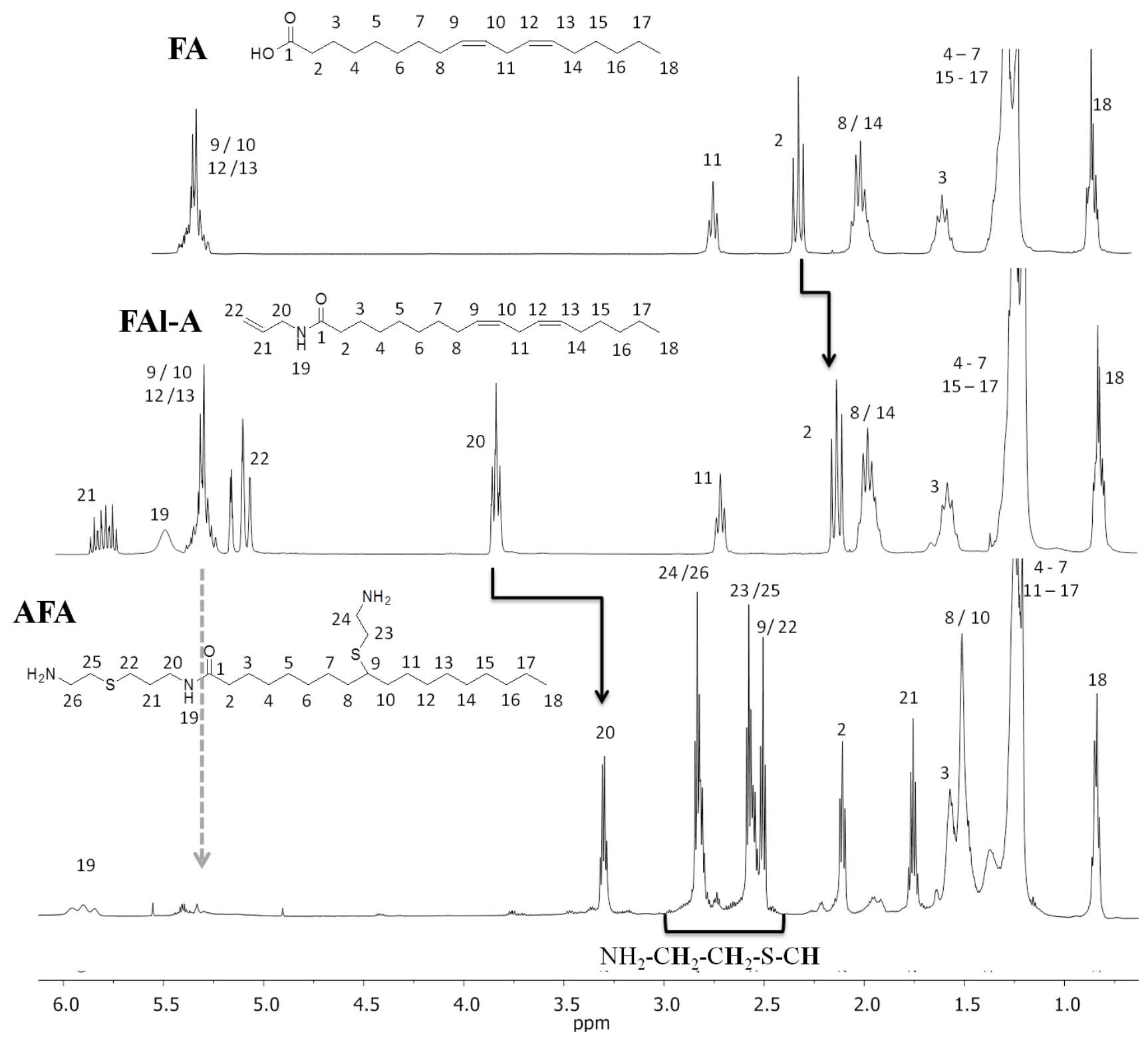

FIGURE $2^{1} \mathrm{H}$ NMR spectra of FA, FAl-A and AFA $\left(\mathrm{CDCl}_{3}\right)$.

\section{Amination of fatty amides}

The second step in the synthesis of the aminated fatty (di)amides consisted of grafting of amine 
groups to the double bonds of the fatty (di)amides, as shown in Figure 1. Several pathways for fatty polyamines synthesis have been previously reported using aziridine, ${ }^{20}$ hydrazine ${ }^{21,22}$ and nitrile. ${ }^{23}$ Thiol-ene coupling is a versatile synthetic tool for the modification of unsaturation to a reactive function (i.e., alcohol, amine, carboxylic acid). The mechanism, ${ }^{8,40,41}$ the effect of the lipid structure ${ }^{42}$ and the $[\mathrm{SH}] /[\mathrm{C}=\mathrm{C}]$ ratio $^{43}$ for the conversion of vegetable oil to lipidic polyols using mercaptoethanol have been investigated. The reaction can be performed under air with limited side reactions ${ }^{44}$ via a thermal or photochemical pathway. The radical addition to the double bond have rarely been reported using a thiol bearing amine group (cysteamine hydrochloride $(\mathrm{CAHC})$ ), as summarized in Figure $3 .^{28,45}$ The thermal-initiated TEC to polyisoprene has been previously reported with a low yield $(20 \%)(2$ equiv. of cysteamine/double bond) ${ }^{46}$ However, polybutadiene was successfully converted in 50-80\% yield (1.6 to 10 equiv. of $\mathrm{CAHC} / \mathrm{C}=\mathrm{C}$ ) ${ }^{47,48}$ In addition, Magenau ${ }^{49}$ reported that the thermal-initiated TEC of cysteamine or CAHC (1.5 equiv.) to polyisobutylene was not successful due to the formation of athiolate group, which affected the radical addition.

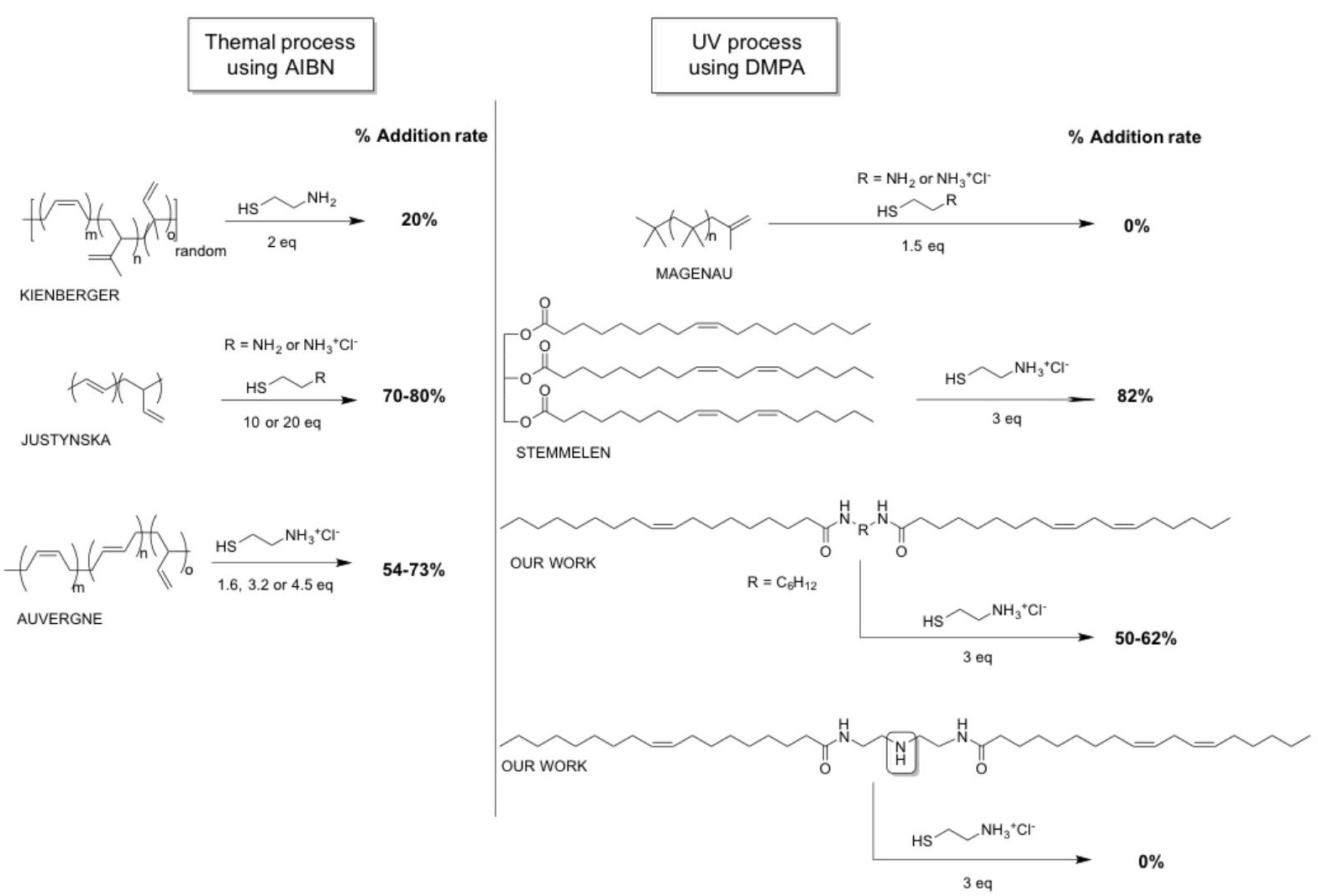


FIGURE 3Thermally initiated and photoinitiatedTEC reactionsof various bio-based derivatives.

Our group has previously reported the functionalization of grapeseed oil using CAHC with UV irradiation. ${ }^{27}$ Thisstudy extended this synthetic strategy to other fatty derivatives, and special attention was focused on fatty mono- and diamides. The optimal conversion rate of the photoinitiated TEC can be achieved with a large excess of thiol to favor thiylover thiolate ${ }^{50}$ After appropriated purification, the addition rate of the $\mathrm{RS}^{\circ}$ radical on the fatty amide was estimated by ${ }^{1} \mathrm{H}$ NMR analysis based on the characteristic peaks of ethylenic protons between 5.0 and $6.0 \mathrm{ppm}$ and the appearance of peaks at $3.7\left(\mathrm{~S}-\mathrm{CH}_{2}-\underline{\mathrm{CH}}_{2}-\mathrm{NH}_{2}\right), 2.7\left(\mathrm{~S}-\mathrm{C}_{2}-\mathrm{CH}_{2}-\mathrm{NH}_{2}\right.$ and/or $\underline{\mathrm{C}}_{2}-\mathrm{S}-\mathrm{CH}_{2}-$ $\left.\mathrm{CH}_{2}-\mathrm{NH}_{2}\right)$ and $2.5 \mathrm{ppm}\left(\mathrm{C}-\mathrm{S}-\mathrm{CH}_{2}-\mathrm{CH}_{2}-\mathrm{NH}_{2}\right)$ (Figure 2). The conversion rates of the fatty (di)amideswere evaluated both based on the consumption of the double bond and the addition of the thiol reactant. The differencein the conversion can be explained by side reactions including oligomerization and oxidation. ${ }^{8,51,52}$ With HDA-FDA, the double bonds disappeared in $80 \%$ conversion, and thiol was added to the double bond in $62 \%$ conversion. For DETA-FDA, a low conversion rate to AFDETA was observed with only $18 \%$ consumed double bonds and no addition of the thiol reactant. The absence of radical addition on DETA-FDA may be due to the secondary amine group converting thiol to thiolate and reducing the concentration of SH able to form $S^{\circ}$, as previously mentioned by Magenau.

The quasi-disappearance of FAl-A unsaturations and $93 \%$ of thethiol added to the double bonds yieldedaminated fatty amide (AFA). A small difference between the consumed double bonds and added thiolswas observed. The higher conversion rate compared to HDA-FDA may be due tothe terminal unsaturation in FAl-A, which is more reactive than the internal one in the TEC 
reaction. $^{53}$

\section{Curing between two fattycomponents}

TEC is a versatile method for synthesizing polyamines with amide or diamide structures.However, only amide one (AFA)wasemployed with epoxidized linseed oil (ELO) to elaborate a fully plant oil-epoxy system because diamide curing agents (AFDA) were immiscible with ELO. The poor solubility of AFDA is due toits high crystallinity resulting in numerous hydrogen bonds.Primary amines are more reactive than secondary ones and were chosen to balance the less accessible internal oxiranes of ELO compared to the terminal ones in the DGEBA system. Becausethe two $\mathrm{N}-\mathrm{H}$ bondsin the primary amine react with two equivalents of epoxy, curing between AFA and ELO was investigatedbecause ELO exhibits six oxirane groups per triglyceride unit. The reactive mixture was prepared with 1 equiv. of ELO (equivalent epoxide weight $=162.33$ g.equiv. $^{-1}$ ) to 1.5 equiv. of AFA (equivalent amine weight $=118.75$ equiv. $\left.^{-1}\right){ }^{9}$

\section{a) Thermal analyses of the reactive mixture}

The temperature zone corresponding to the reaction between the AFA and ELO mixture was determined using DSC in dynamic mode, as shown in Figure 4. The exothermic peak of the crosslinking reaction was observed between 80 and $240{ }^{\circ} \mathrm{C}$ with a maximum at $190{ }^{\circ} \mathrm{C}$. The asymmetrical shape of the exothermic peak was most likely due to thermal degradation of the polymeric network at high temperature $\left(\mathrm{T}>240{ }^{\circ} \mathrm{C}\right)$. Therefore, the $\Delta \mathrm{H}$ value obtained from the integration of the exothermic peak area is not considered to be specific to only the crosslinking reaction. The "apparent" value was close to $150 \mathrm{~J}^{-1}{ }^{-1}$. The temperature zone of the thermal 
degradation of the reactive mixture can be better evaluatedusing thermogravimetry. To take into account the influence of both the time and temperature on the degradation process, TGA analysis was performed at a slow heating rate $\left(1^{\circ} \mathrm{C} \cdot \mathrm{min}^{-1}\right)$. Then, the degradation inception was defined as the temperature where the sample residual weight was approximately $98 \%$ of the initial value and was determined to be approximately $160{ }^{\circ} \mathrm{C}$.

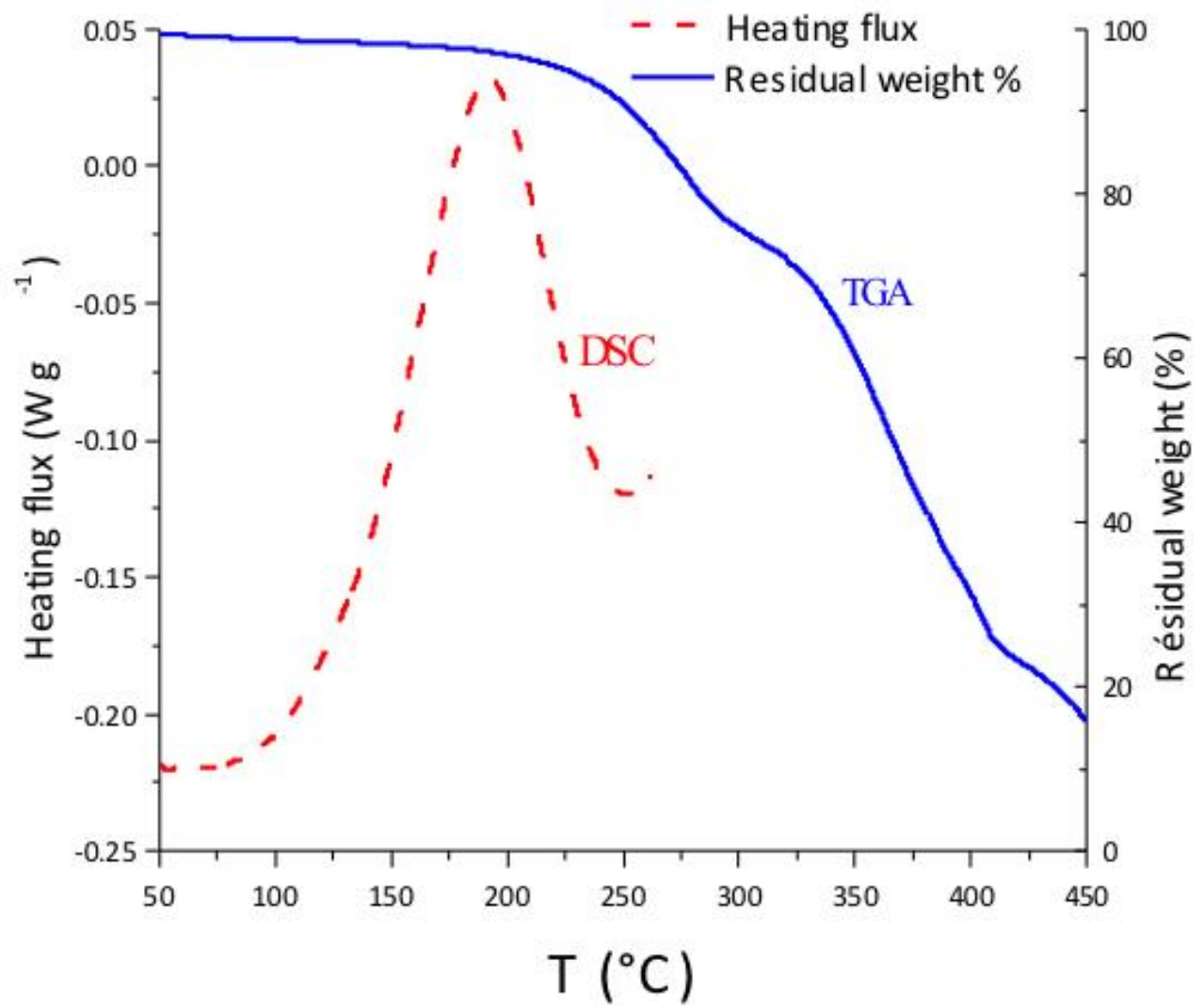

FIGURE 4DSC and TGA analyses of the AFA-ELO reactive mixture.

\section{b) Physico-chemical study of the curing reaction}

The characterization of the crosslinking process was investigated using rheological measurements. First, experiments were performed to determine the evolution of the complex shear modulus as a function of time at constant temperature. Figure 5a shows the results from the kinetic experiments conducted at 80 and $120^{\circ} \mathrm{C}$. At $120^{\circ} \mathrm{C}$, the liquid-solid transition occurred 
more abruptly and at shorter times $(\mathrm{t} \sim 2.5 \mathrm{~h})$ due to the activation temperature of the crosslinking process. In both cases, the limit values of $G^{\prime}$ and $G$ "' were determined to be less than those of a glassy material. Therefore, no vitrification was observed at 80 and $120{ }^{\circ} \mathrm{C}$. However, the higher value of $G^{\prime}$ at the end of the analysis at $120{ }^{\circ} \mathrm{C}$ indicated that the curing process was conducted ata higher degree than that obtained at $80{ }^{\circ} \mathrm{C}$. A commercial fatty diamine from the dimerization of fatty acids (i.e., Priamine 1075 from Croda) was used as the curing agent with ELOand compared to AFA. The rheological kinetics at $120^{\circ} \mathrm{C}$ exhibited an earlier liquid-solid transition for AFA-ELO (2.5h compared to 4h), as shown in Figure 5b, and similar to aminatedgrapeseed oil $\left(2 \mathrm{~h}\right.$ ), which was previously discussed (Table 1). ${ }^{27}$ In addition, AFA permitted a shorter complete crosslinking reaction after $30 \mathrm{~h}$ instead of several days for Priamine-

\section{ELO.}
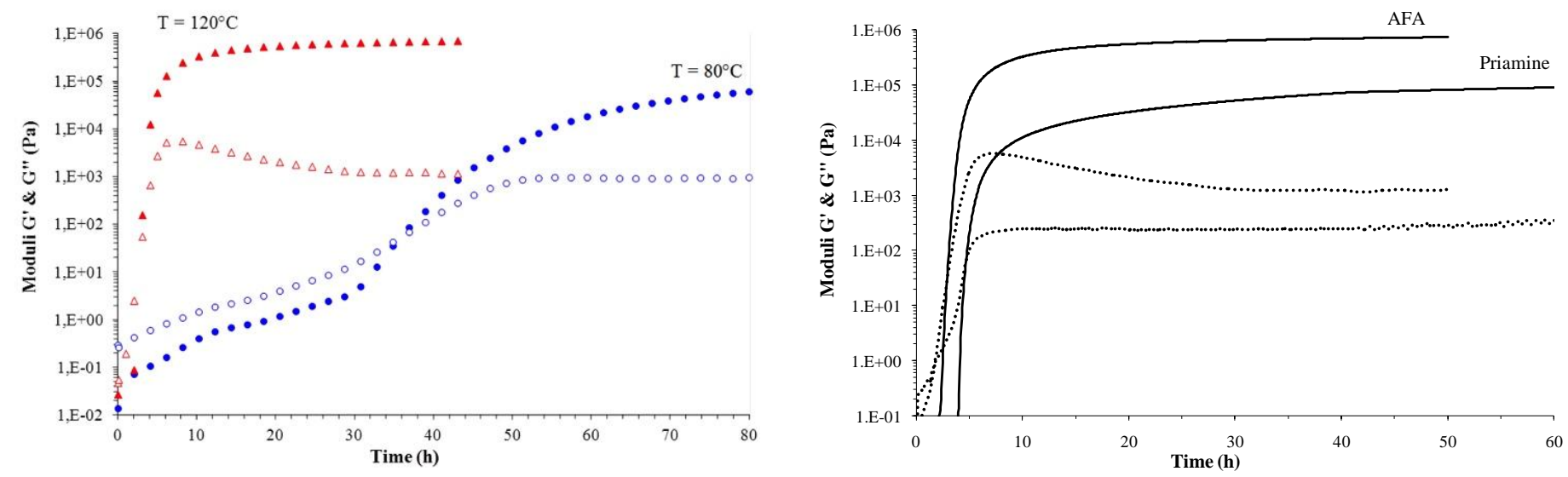

FIGURE 5 (left): G' (whole symbol) and G'" (empty symbol) as a function of the temperature of the AFA-ELO mixture at $80{ }^{\circ} \mathrm{C}$ (circle) and $120{ }^{\circ} \mathrm{C}$ (triangle); (right). Comparison of the rheological kinetics of ELO with AFA and Priamine at $120^{\circ} \mathrm{C}$. 
Table 1. Characteristics of the epoxy thermosets based on lipidic curing agents and ELO.

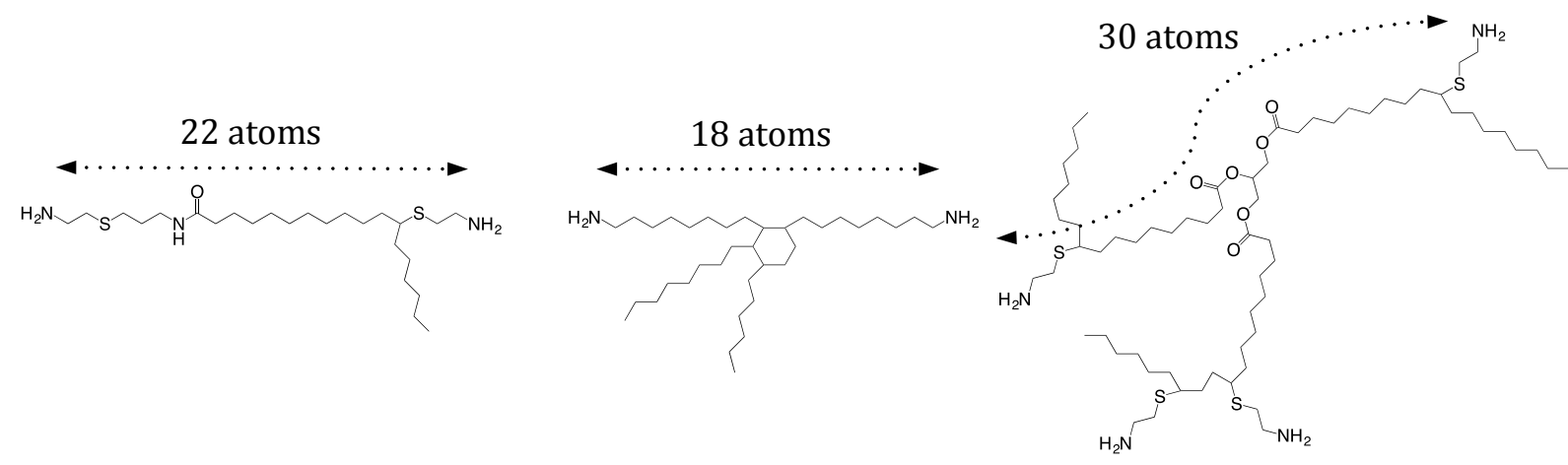
AFA
Priamine
aminated oil 27

\begin{tabular}{cccc}
\hline $\mathbf{T g}\left({ }^{\circ} \mathbf{C}\right)$ & -9 & -31 & -38 \\
$\mathbf{E}(\mathbf{G P a})$ & 2.0 & 0.7 & 1.0 \\
$\mathbf{G}^{\prime}(\mathbf{M P a}){ }^{\mathbf{a}}$ & 25 & 1.6 & 4.2 \\
$\mathbf{a}(\mathbf{n m})^{\mathbf{b}}$ & 1.2 & 2.9 & 2.1 \\
$\mathbf{t}_{\text {gel }}(\mathbf{h})^{\mathbf{c}}$ & 2.5 & 4 & 2 \\
\hline
\end{tabular}

${ }^{a}$ : Material elasticity at the beginning of the rubbery plateau. ${ }^{b}$ : Average size calculated using Equation 1 . $^{\mathrm{c}}$ : Deduced from rheological kinetic realized at $120^{\circ} \mathrm{C}$.

\section{Thermomechanical characterization of the epoxy thermoset}

The thermomechanicalbehavior of the AFA-ELO and Priamine-ELO resulting materials was investigated from -150 to $150{ }^{\circ} \mathrm{C}$, as shown in Figure 6 . For temperaturesless than $-25{ }^{\circ} \mathrm{C}$, the polymer was in a glassy state with amechanical rigidity of approximately 2.0 and $0.7 \mathrm{GPa}$, respectively, as shown in Table 1. A similar value was previously reported for aminated oil. ${ }^{27} \mathrm{An}$ abrupt decrease of the storage modulus, which is characteristic of the polymer glassy transition $\left(\omega=1 \mathrm{rad} . \mathrm{s}^{-1}\right)$, was observed. The Tg value of the cured AFA-ELO was approximately $-9{ }^{\circ} \mathrm{C}$, whichis quite different from the temperatures used in the rheological kinetic experiments ( 80 or $\left.120{ }^{\circ} \mathrm{C}\right)$. Therefore, no vitrification was detected during these kinetic analyses.In 
contrast,Priamine and aminated oil exhibited lower Tg values of -31 and $-38^{\circ} \mathrm{C}$, respectively. The presence of dangling alkyl chains in the commercial diamine structure may explain the surprisingvalue.

For $\mathrm{T}>30{ }^{\circ} \mathrm{C}$, the $\mathrm{G}$ ' value was slightly dependent on the temperature. This domain was identified as being characteristic of the rubbery plateau of the material. At higher temperatures, the absence of a melting or softening zone confirmed that the reaction between AFA and ELO produced an infusible and three-dimensional macromolecular network. The average size (a) of its mesh can be evaluated using the expression for the rubber elasticity law (Equation 1):

$$
G^{\prime}=\frac{k_{B} T}{a^{3}}
$$

where $G^{\prime}$ is the value of the material elasticity at the beginning of the rubbery plateau ( $G^{\prime}$ $\left.=2.5^{*} 10^{6} \mathrm{~Pa}\right), \mathrm{T}$ is the corresponding temperature $(\mathrm{T}=303.15 \mathrm{~K})$ and $\mathrm{k}_{\mathrm{B}}$ is Boltzmann's constant $\left(k_{B}=1.3806503 \times 10^{-23} \mathrm{~J} \cdot \mathrm{K}^{-1}\right)$. Even if an epoxy network does not obey a Gaussian dynamics, the previous relationshipprovides an interesting comparison of different thermoset materials. For the AFA-ELO, Priamine-ELO and aminated oil-ELO systems, the average size was calculated to be a =1.2, 2.9 and $2.1 \mathrm{~nm}$, respectively. As expected, the AFA network was denser than that of the aminated oil-ELO system,andthe Priamine network was surprisingly more flexible than the last one. This result can be explained by the presence of dangling chains in the Priamine structure that plasticized the material and increased the molecular distance between the two reactive amine functions. 


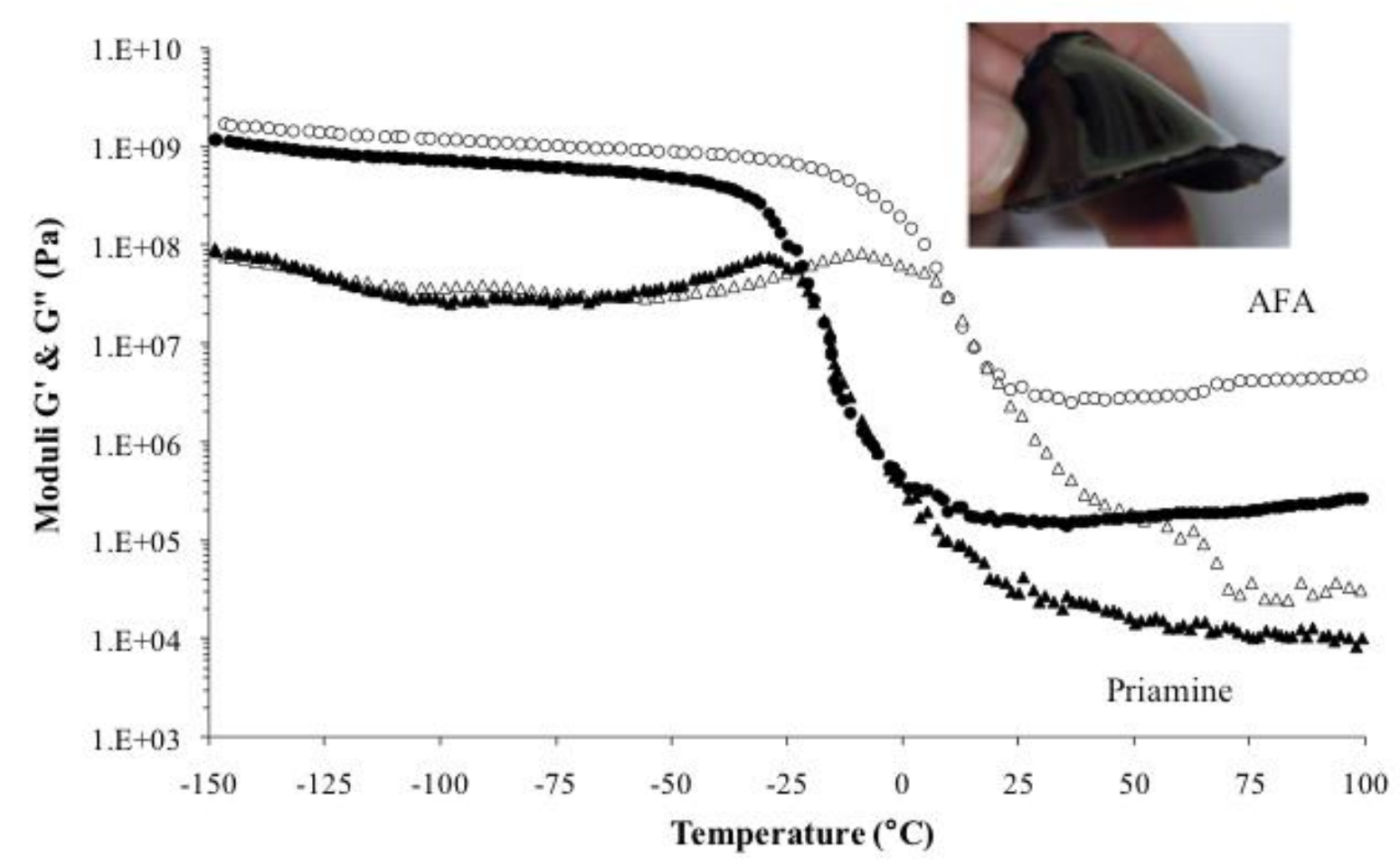

FIGURE 6Thermomechanical profiles of AFA-ELO (G': O - G”: $\triangle$ ) \&Priamine-ELO (G': G”: $\mathbf{\Delta})$.

A more careful examination of the AFA-ELO thermomechanical curves indicated that the main relaxation peak appears to be composed of two distinct parts. To gain further insight, a new series of thermomechanical analyses were performed at different shearing angular frequency $(\omega)$ values, as shown in Figure 7. It is important to note that both the position and shape were affected by the $\omega$ change. Because a shift in the relaxation peak to higher temperatures is expected according to the time-temperatureequivalence principle, the splitting into two components was more surprising. This evolution can be explained because each "elementary peak" obeyed the WLF law but with specific $\mathrm{C}_{1}$ and $\mathrm{C}_{2}$ coefficients (Equation 2): 


$$
\log \frac{\omega}{\omega_{0}}=\frac{C_{1} *\left(T_{\alpha}-T_{0}\right)}{C_{2}+T_{\alpha}-T_{0}}
$$

where $T_{0}$ is the temperature at the maximum of the $\alpha$ peak when the shearing was equal to $\omega_{0}=1$

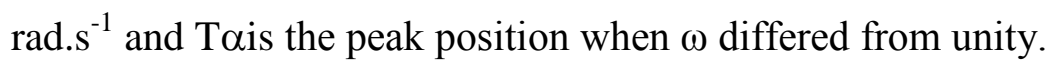

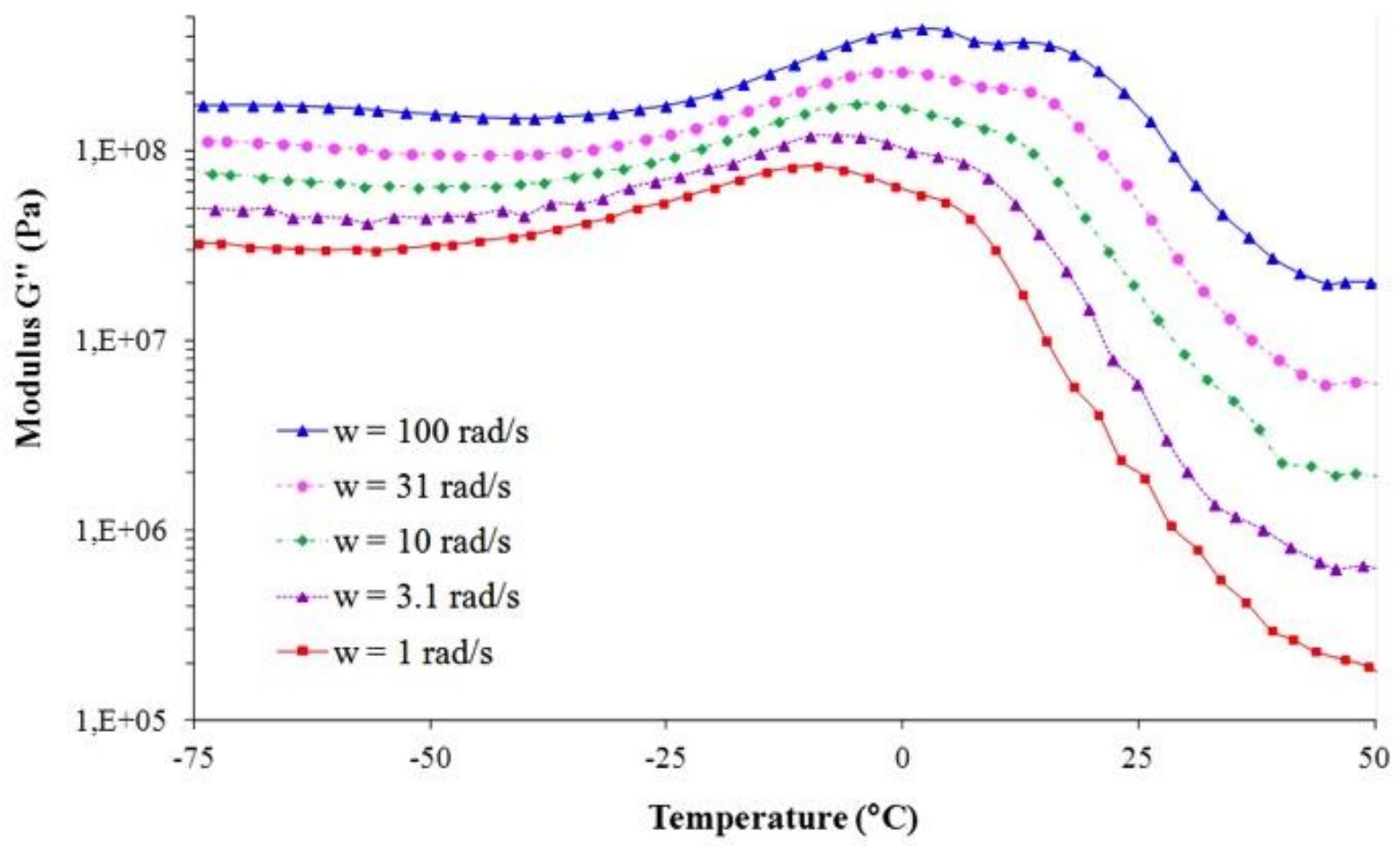

FIGURE 7Influence of the shearing angular frequency on the position and shape of the main relaxation peak.

The high-temperature elementary peak was more influenced by the frequency change. Its shift along the temperature axis was more pronounced than that characteristic of the "low temperature contribution," which resulted in easier observation of each elementary component. Two consecutive thermomechanical analyses on the same sample were helpful in understanding the 
origin of each "sub peak". Indeed, a comparison of the results obtained for both runs indicated that the high temperature elementary peak moved to a higher temperature position.However, the low temperature contribution was nearly unchanged (Figure 8-a). Pursuing the crosslinking process seemed to not be very credible because the reaction was previously considered to be fully achieved.

Chocinskiet al. ${ }^{54}$ have already reported this phenomenon with another epoxy-amine thermoset polymer. The formation of a new relaxation peak at a higher temperature than that of the glass transition phenomenon was due to the oxidation of the material surface. This phenomenon was reversible because the removal of the oxidized layer by mechanical polishing induced the disappearance of the high temperature peak. To confirm this hypothesis, a similar mechanical treatment was performed on a new AFA-ELO sample. A thickness of $200 \mu \mathrm{m}$ was removed on each side of the polymer sample. A comparison of both thermomechanical responses before and after polishing indicated that the polishing induced a strong reduction in both the amplitude and position of the high temperature relaxation peak.However, the principal peak characteristic of the polymer glass transition remained nearly unchanged (Figure 8-b). The consistency of the rubbery elasticity between both types of samples indicated that the high temperature did not result from a denser network. In addition, the oxidation of the external layer removed by polishing was investigated by FTIR spectroscopy (supporting information). Our results supported the conclusions proposed by Chocinski. Because the oxidation did not further induced crosslinking ( $G$ ' unchanged), the residual amine groups may be from the reaction between the oxirane and the primary amines. According to our results, the oxidation of these amine functions reduced the macromolecular mobility, which results in the production of a specific relaxation peak at a higher temperature. 

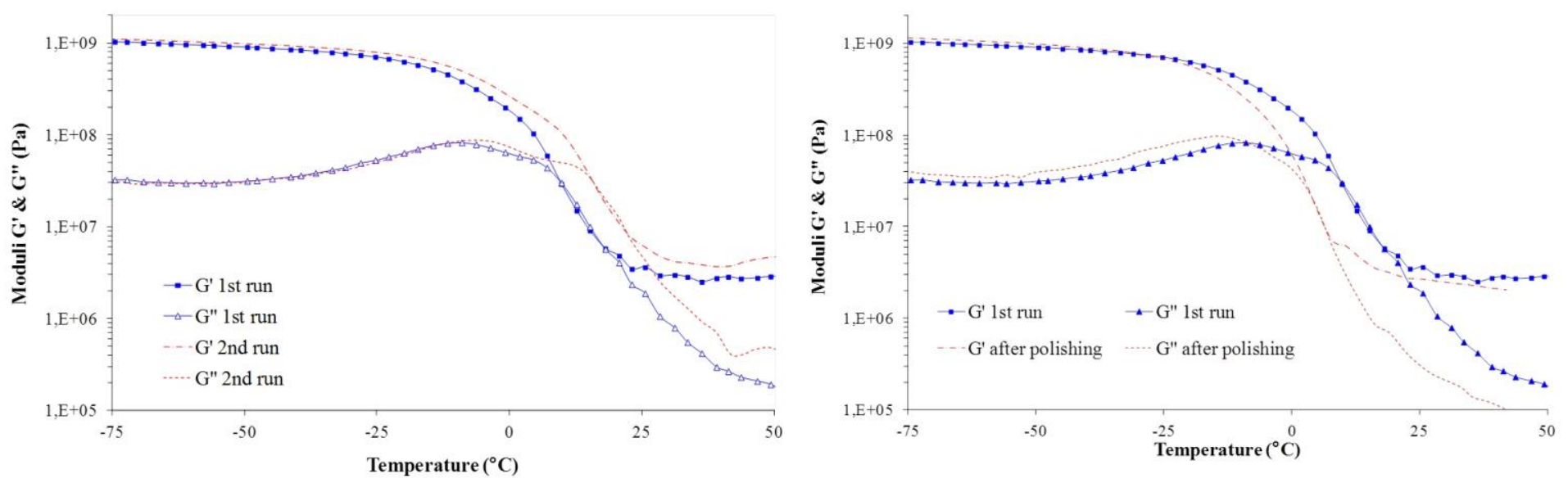

FIGURE8a) Thermomechanical analysis of the cured AFA-ELO mixture $\left(1^{\text {st }}\right.$ run linked symbol, $2^{\mathrm{d}}$ run unlinked symbol). b) Thermomechanical analysis of the cured AFA-ELO mixture before and after polishing (unpolished: linked symbol, polished: unlinked symbol). 


\section{Conclusions}

In this study, novel lipidic diamines wereprepared to extend the type of bio-based amines. The synthesis included a first step involving amidification of fatty acids followed by a thiol-ene coupling, which is a reaction that isunfavorable in the presence of an amine group, present on cysteamine hydrochloride. Although the efficiency of the TEC functionalization depends on the structure of fatty amide, good results were achieved with fatty allyl-amide, which was used as a hardener of epoxidized linseed oil to afford a bio-based epoxy resin with $89 \%$ bio-sourced carbon. Based on theDSC and dynamic rheological analyses,the AFA-ELO system was more reactive than other commercial fatty amides,such as Priamine 1075. In addition, the resulting material was slightly more rigidfor AFA-ELO with a similar behaviorcompared to the material based on aminated grapeseed oil. In-depth studies indicated the presence of an oxidized layer on the resin detected due to the presence of two distinct relaxation peaks and residual amine groups. This oxidation is a surprising and interesting approach for increasing the final thermomechanical performances of the cured material. 


\section{Caption}

FIGURE 1 Synthesis of aminated fatty (di)amides.

FIGURE $2^{1} \mathrm{H}$ NMR spectra of FA, FAl-A and AFA $\left(\mathrm{CDCl}_{3}\right)$.

FIGURE 3 Thermally initiated and photoinitiatedTEC reactions of various bio-based derivatives.

FIGURE 4 DSC and TGA analyses of the AFA-ELO reactive mixture.

FIGURE 5 (left): G' (whole symbol) and G" (empty symbol) as a function of the temperature of the AFA-ELO mixture at $80{ }^{\circ} \mathrm{C}$ (circle) and $120{ }^{\circ} \mathrm{C}$ (triangle); (right).Comparison of the rheological kinetics of ELO with AFA and Priamine at $120^{\circ} \mathrm{C}$.

FIGURE 6Thermomechanical profiles of AFA-ELO (G': O - G': $\triangle$ ) andPriamine-ELO (G':

- G”: $\mathbf{\Delta})$.

FIGURE 7 Influence of the shearing angular frequency on the position and shape of the main relaxation peak.

FIGURE 8 a) Thermomechanical analysis of the cured AFA-ELO mixture $\left(1^{\text {st }}\right.$ run linked symbol, $2^{\mathrm{d}}$ run unlinked symbol). b) Thermomechanical analysis of the cured AFA-ELO mixture before and after polishing (unpolished: linked symbol, polished: unlinked symbol).

TABLE 1. Characteristics of the epoxy thermosets based on lipidic curing agents and ELO. 


\section{References}

1. Raquez J.M., Deléglise M., Lacrampe M.F., Krawczak P., Prog. Polym. Sci. 2010, 35, 487509.

2. Flaris V., Singh G., J. Vinyl Addit. Technol. 2009, 15, 1-11.

3. Xia Y., Larock R.C., Green Chem. 2010, 12, 1893-1909.

4. Seniha Güner F., Yağcı Y., Tuncer Erciyes A., Prog. Polym. Sci. 2006, 31, 633-670.

5. Sharma V., Kundu P.P., Prog. Polym. Sci. 2006, 31, 983-1008.

6. Hill K., Pure Appl. Chem. 2000, 72, 1255-1264.

7. DesrochesM., Escouvois M., Auvergne R., Caillol S., Boutevin B., Polym. Rev. 2012, 52, 3879.

8. a) Desroches M., Caillol S., Lapinte V., Auvergne R., Boutevin B., Macromolecules 2011, 44, 2489-2500. b) Pham P. D., Lapinte V., Raoul Y., Robin J.-J. J. Polym. Sci. Part A: Polym. Chem. 2014,1597-1606.

9. Meier M.A.R., Metzger J.O., Schubert U.S., Chem. Soc. Rev. 2007, 36, 1788-1802.

10. Pascault J.P., R. Williams J.J., Epoxy Polymers: New Materials and Innovations, John Wiley \& Sons, 2010.

11. Chakrapani S., J.V., J. Macromol. Sci., Pure Appl. Chem. 1998, A35, 691-710.

12. Park S.J., Jin F.L., Lee J.R., Macromol. Rapid Commun. 2004, 25, 724-727.

13. Shibata M., Nakai K., J. Polym. Sci. Part B: Polym. Phys. 2010, 48, 425-433.

14. Czub P., Macromol. Symp. 2009, 277, 162-170.

15. Mahendran A.R., Aust N., Wuzella G., Kandelbauer A., Macromol. Symp. 2012, 311, 18-27.

16. Gerbase A., Petzhold C., Costa A., J. Am. Oil Chem. Soc. 2002, 79, 797-802.

17. Liu Z.S., Erhan S.Z., Xu J., Calvert P.D., J. Appl. Polym. Sci. 2002, 85, 2100-2107. 
18. Girard-Reydet E., Riccardi C.C., Sautereau H., Pascault J.P., Macromolecules 1995, 28, 75997607.

19. Caouthar A.A., Loupy A., Bortolussi M., Blais J.C., Dubreucq L., Meddour A., J. Polym. Sci. Part A: Polym. Chem. 2005, 43, 2480-2491.

20. Biermann U., Fuermeier S., Metzger J.O., Fett/Lipid 1998, 100, 236-246.

21. Zhao H.P., Zhang J.F., Susan Sun X., Hua D.H., J. Appl. Polym. Sci. 2008, 110, 647-656.

22. Biswas A., Sharma B.K., Willet J.L., Vermillion K., Erhan S.Z., Cheng H.N., Green Chem. 2007, 9, 85-89.

23. Biswas A., Sharma B.K., Willett J.L., Erhan S.Z., Cheng H.N., Energy \& Environ. Sci. 2008, $1,639-644$.

24. Biswas A., Sharma B.K., Doll K.M., Erhan S.Z., Willett J.L., Cheng H.N., J. Agri. Food Chem. 2009, 57, 8136-8141.

25. Corma A., Iborra S., Velty A., Chem. Rev. 2007, 107, 2411-2502.

26. Waidner T.C., Grandquist V.M., ARR-MAZ Custom Chemicals US Patent 0155934, 2007.

27. Stemmelen M., Pessel F., Lapinte V., Caillol S., Habas J.P., Robin J.J., J. Polym. Sci. Part A: Polym. Chem. 2011, 49, 2434-2444.

28. Turunc O., Firdaus M., Klein G., Meier M.A.R., Green Chem. 2012, 14, 2577-2583.

29. Roe E., Stutzman J., Scanlan J., Swern D., J. Am. Oil Chem. Soc.1952, 29, 18-22.

30. Ohba Y., Kanao Y., Takatsuji M., Ito M., Yabuta N., Nojima H., Kita Y., Tetrahedron 2007, 63, 3754-3761.

31. Maugard T., Remaud-Simeon M., Petre D., Monsan P., Tetrahedron 1997, 53, 5185-5194.

32. Prasad K.V.S.R.G., Bharathi K., Haseena B.B., Int. J. Pharm. Sci. Rev. Res. 2011, 8, 108-119. 
33. S Feairheller., Bistline R., Bilyk A., Dudley R., Kozempel M., Haas M., J. Am. Oil Chem. Soc. $1994,71,863-866$.

34. Folmer B., Holmberg K., Klingskog E., Bergström K., J. Surf. Detergents 2001, 4, 175-183.

35. Khoe T.H., Otey F., Frankel E.N., Cowan J.C., J. Am. Oil Chem. Soc. 1973, 50, 331-333.

36. Kolancilar H., J. Am. Oil Chem. Soc. 2004, 81, 597-598.

37. Bistline R., Hampson J., LinField W., J. Am. Oil Chem. Soc. 1983, 60, 823-828.

38. Wu Y., Herrington P., J. Am. Oil Chem. Soc. 1997, 74, 61-64.

39. Farshori N.N., Ahmad A., Khan A.U., Rauf A., Eur. J. Med. Chem. 2011, 46, 1433-1438.

40. Chatgilialoglu C., Samadi A., Guerra M., Fischer H., ChemPhysChem 2005, 6, 286-291.

41. Hoyle C.E., Bowman C.N., Angew. Chem. Int. Ed. 2010, 49, 1540-1573.

42. Schwab A., Gast L., J. Am. Oil Chem. Soc. 1970, 47, 371-373.

43. Bantchev G.B., Kenar J.A., Biresaw G., Han M.G., J. Agri. Food Chem. 2009, 57, 1282-1290.

44. Boileau S., Mazeaud-Henri B., Blackborow R., Eur. Polym. J. 2003, 39, 1395-1404.

45. Boyer C., Loubat C., Robin J.J., Boutevin B., J. Polym. Sci. Part A: Polym. Chem. 2004, 42, $5146-5160$.

46. Kienberger J., Noormofidi N., Mühlbacher I., Klarholz I., Harms C., Slugovc C., J. Polym. Sci. Part A: Polym. Chem. 2012, 50, 2236-2243.

47. Justynska J., Hordyjewicz Z., Schlaad H., Polymer 2005, 46, 12057-12064.

48. Auvergne R., Desroches M., Clerc S., Carlotti S., Caillol S., Boutevin B., React. Funct. Polym. 2012, 72, 393-401.

49. Magenau A.J.D., Chan J.W., Hoyle C.E., Storey R.F., Polym. Chem. 2010, 1, 831-833.

50. Cramer N.B., Reddy S.K., Cole M., Hoyle C., Bowman C.N., J. Polym. Sci. Part A: Polym. Chem. 2004, 42, 5817-5826. 
51. Brummelhuis N., Diehl C., Schlaad H., Macromolecules 2008, 41, 9946-9947.

52. Black M., Rawlins J.W., Eur. Polym. J. 2009, 45, 1433-1441.

53. Roper T.M., Guymon C.A., Jönsson E.S., Hoyle C.E., J. Polym. Sci. Part A: Polym. Chem. $2004,42,6283-6298$.

Chocinski-Arnault L., Olivier L., Lafarie-Frenot M.C., Mat. Sci. Eng.: A 2009, 521-522, 287290. 